\title{
IMITATIVE STUDY OF THE UPPER LIMIT OF THE NODES- REPEATERS AMOUNT IN THE OLSR PROTOCOL
}

\author{
Volodymyr V. Maksimov \\ Institute of Telecommunication Systems \\ Igor Sikorsky Kyiv Politechnic Institute, Kyiv, Ukraine
}

Background. At present, the demand in MANET networks is determined by the inherent advantages of these networks over fixed networks, especially in emergency situations. The topology in such networks is extremely dynamic, which required the development of special routing protocols. Although the basics of the theory of the OLSR protocol, which is widely used in these networks, are well known, however, the development of mobile networks requires constant refinements of theoretical positions in accordance with new data on how to calculate the number of multipoint repeaters.

Objective. The aim of the paper is to find analytical expressions for calculating the upper limit of the number of multipoint repeaters, the probability of the location of two-hop nodes at the maximum distance from the reference, and checking the correspondence of the results obtained using simulation.

Methods. Analytical methods of calculation are used, as well as simulation modeling in the NS-2 software package.

Results. Analytical expressions are obtained for calculating the upper limit of the number of multipoint repeaters and the probability of the location of two-hop nodes at the maximum distance from the reference node. A simulation was performed to confirm the theoretical results.

Conclusions. The upper bound of the number of one-hop relay nodes is estimated. It is shown that with a low density of nodes in the area under consideration, the value of the upper limit is two times less than that previously determined in the scientific literature. Modeling in the NS-2 software package showed the correspondence of analytical expressions for the calculation of the upper boundary of multipoint repeaters. There are cases when analytical expressions give false results. For these cases, it was proved that regardless of the network density, each two-hop node that is at the maximum distance from the reference node must have its own multipoint repeater. The probability of the location of two-knot nodes at the maximum distance from the reference node is determined.

Keywords: ad hoc network; OLSR protocol; multipoint repeater; amount of service information; NS-2 modeling.

\section{INTRODUCTION}

Today, there are a large number of routing methods and protocols, the main of which are classified as follows [1]: proactive (FSR, FSLS, OLSR, TBRPF), reactive (AODV, DSR), hierarchical (HSR, CGSR, ZRP), geographic (GeoCast, LAR, DREAM, GPSR).

Among the most commonly used routing protocols in wireless networks MANET has a protocol called OLSR (Link State Routing Protocol) [2], which devotes a lot of work. So in [3] the principle and operation of multipoint repeaters (MPR) is discussed and a heuristic approach is proposed for selecting MPR in a mobile wireless environment; [4-7] are aimed at optimizing the work of the OLSR protocol, which is a complex task, because the protocol contains more than a dozen customizable parameters. In [8$10]$, the problem of finding the upper limit of the number of MPR nodes is considered.
In this paper, the study was conducted over the Link State Routing Protocol (OLSR) protocol, which was developed for ad hoc networks specifically as a proactive protocol and based on the concept of multipoint relay multireferral (MPR) [2, 3]. It means that each network node $\mathrm{m}$ selects several nodes from its neighbors (the nodes with which it has a connection). As a result, a set of nodes MPR(m) is formed on the network in such a way that all nodes located in a sphere with a radius of 2 steps from node $\mathrm{m}$ (neighbors of neighbors) have symmetric channels with MPR(m). That is, MPR nodes are associated with all nodes in a sphere with a radius of 2 steps.

For each MPR, a list of neighboring nodes that have selected it as an MPR is generated - the MPR Selectors (MPRS) list. The network in the $\mathrm{TC}$ - packets only transmits information about the state of the connections between the MPR and its MPRSs, which can significantly reduce the number of transfers of service packets compared with the avalanche. From the above, it follows 
that the amount of service information that is transmitted along with the useful traffic in the OLSR protocol depends on the number of MPR nodes.

From the above, it follows that when designing an ad hoc network using the OLSR routing protocol, the overestimation of the upper bound of the MPR nodes can lead to an overestimated estimate of the number of service packets transfers and, accordingly, an undervalued network bandwidth.

To find the upper limit of the number of MPR nodes, it is necessary to determine the area $A(\theta)$ outside the zone of reception of the signal of these nodes for two cases: 1) the area A ( $\theta)$ lies in the circle $\mathrm{K}_{2}-\mathrm{K}_{1}$ at the corner $\theta \leq 2 \pi / 3$ (Fig. 1), 2) area $\mathrm{A}(\theta)$ lies both in the circle $\mathrm{K}_{2}$ and in the circle $\mathrm{K}_{1}$ at the corner $\theta>2 \pi / 3$ (Fig. 2). After determining the area $A(\theta)$, taking into account the density of the network, the upper limit of the MPR nodes is determined.

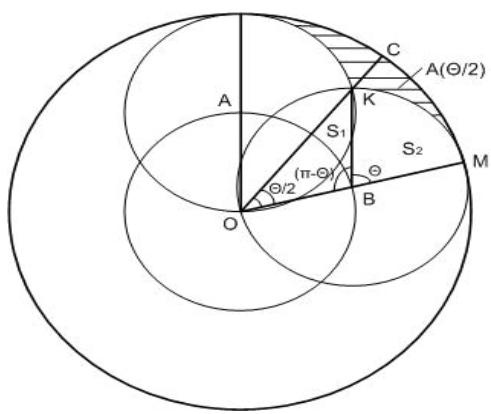

Fig. 1 The domain of the set of points $\mathrm{A}(\theta)$ with $\theta \leq$ $2 \pi / 3$

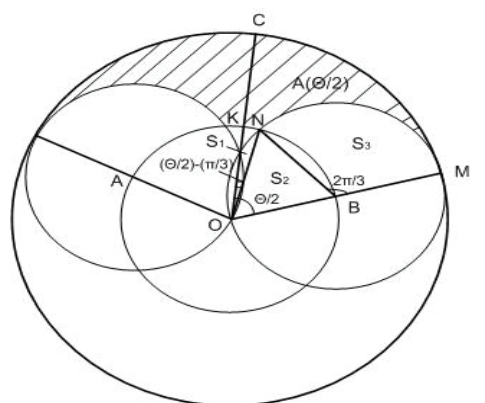

Fig. 2 The domain of the set of points $\mathrm{A}(\theta)$ with $\theta>$ $2 \pi / 3$

In [9] when determining in $2 \mathrm{D}$ the average number of MPR nodes is given without proof the following statement:

Suppose there are two circles $\mathrm{K}_{1}$ and $\mathrm{K}_{2}$ in radius 1 and 2 , respectively, with the center at the point $\mathrm{A}$. Let two points $\mathrm{A}$ and $\mathrm{B}$ be in the circle $\mathrm{K}_{1}$ and are separated by an angle $\theta$ whose vertex is in the center of the circle. Let $A(\theta)$ be the region of the set of points $\mathrm{K}_{2}$ such that

- points are not in $\mathrm{K}_{1}$;

- the points are in a sector with a center at the point $\mathrm{O}$, bounded by $\mathrm{A}$ and $\mathrm{B}$;
- the dots are more than 1 inches from A and $B$.

Then if $\theta \leq 2 \pi / 3$, so $A(\theta)=\theta-\sin \theta$. Otherwise $A(\theta)=A\left(\frac{2 \pi}{3}\right)+3\left(\theta-\frac{2 \pi}{3}\right)$.

In [10] this theorem is proved and it is shown that under the above conditions:

Then if $\theta \leq 2 \pi / 3$, so $A(\theta)=\theta-\sin \theta$. Otherwise $A(\theta)=A\left(\frac{2 \pi}{3}\right)+\frac{3}{2}\left(\theta-\frac{2 \pi}{3}\right)$.

Formula (2) allows you to determine the upper limit of the $D_{N}$ of the number of MPR nodes for the network. Given that the density of the network $D=\frac{N}{L^{2}}, N$ is the number of nodes in the network, located on the area bounded by the sides of the square in length $L=4 R, R=1$ - the maximum radius of one node, this theorem can be written as follows:

Theorem 1a. When $L$ is fixed and $N$ is growing, the upper limit of the number of MPR nodes $D_{N}$ at $\theta \leq \frac{2 \pi}{3}$ is less than $D_{N}<\frac{3 \pi}{2}\left(\frac{N}{6}\right)^{\frac{1}{3}}$, and for $\theta>\frac{2 \pi}{3}$ it is less than

$D_{N}<3 \pi \frac{N}{16}+3 \pi\left(\frac{N}{48}\right)^{\frac{1}{3}}\left(1-\pi \frac{N}{16}\right)^{\frac{2}{3}}$,

where $\theta$ is the angle between adjacent MPR nodes.

To test the efficiency of the theorem in Network Simulator 2 (NS-2) we considered three types of networks with different number of nodes: the "grid" (Fig. 1a), the "tape" (Fig. 1b) and the "arbitrary" (Fig. 1c). The nodes were located within the area bounded by the edge of the square with $\mathrm{L}=80 \mathrm{~m}$. For each variant of the network, there was an upper limit of the number of MPR nodes by calculations by formulae (3), (4) and simulation.

\section{Simulation results}

Fig. 3 shows three types of networks: "grid" (3a), "tape" (3b) and "arbitrary" (3v). The number of investigated nodes for a grid-type network: $\mathrm{N}=5 ; 9 ; 13 ; 25 ; 41 ; 81 ; 121 ; 225 ; 361$; for a network of "tape" type, whose width is $1=\mathrm{R}$, $\mathrm{N}=5 ; 13 ; 31 ; 39 ; 47 ; 59$; For a network of "arbitrary" number of nodes $\mathrm{N}=50$, which are located within the area bounded by a square with a rib $\mathrm{L}=80 \mathrm{~m}$. For networks of the "grid" and "arbitrary" calculation of MPR nodes was carried out by the formula (3), for the network type "tape" by the formula (4).

The results of calculations are presented in Fig. 4, 5 and 6, respectively.

The simulation results confirm the efficiency of the theorem: in all cases considered, the real number of MPR nodes is always smaller than the maximum number of MPR nodes, which is determined in accordance with the upper limit theorem. 


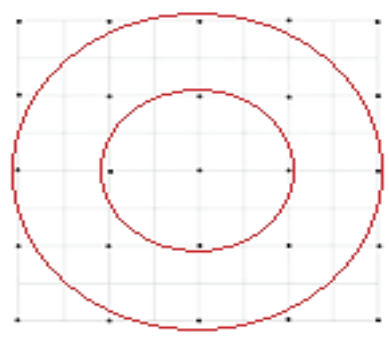

a)

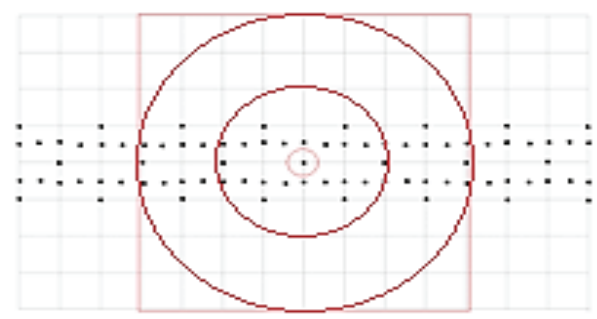

b)

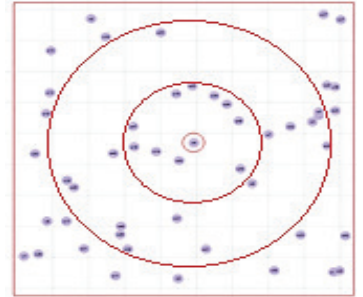

c)

Fig. 3. Three types of networks with different number of nodes: "net", "tape" and "arbitrary"

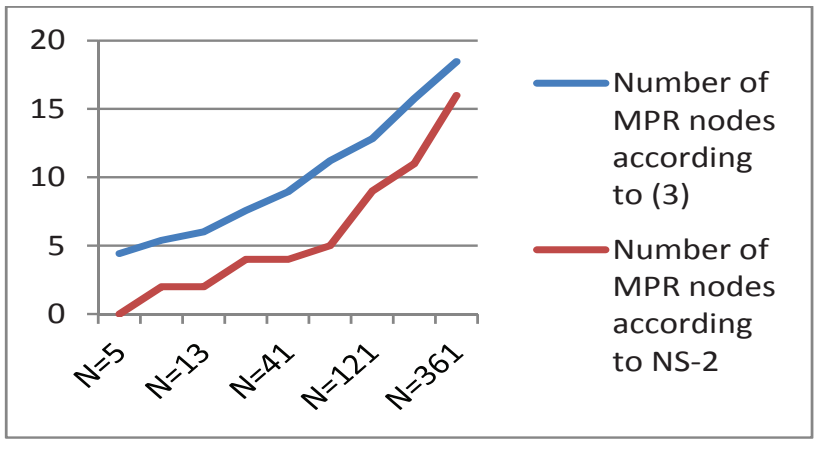

Fig.4 Results of calculating the number of MPR nodes for the "grid" topology

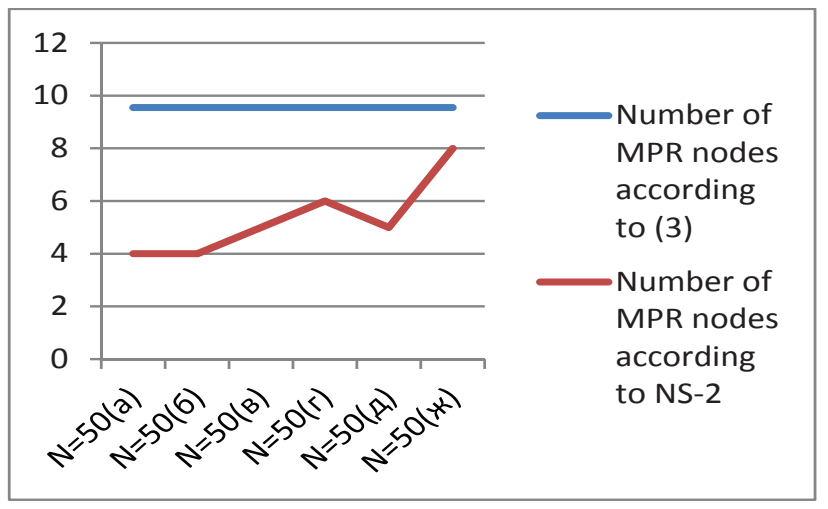

Fig.6 Results of calculating the number of MPR nodes for the "arbitrary" topology

In addition, the simulation results allow us to simplify the theorem by writing it in the following form:

Theorem 1 b. When $\mathrm{L}$ is fixed and $N$ is growing, then the upper limit of the number of MPR nodes $D_{N}$ for $\theta \leq \frac{2 \pi}{3}$ is less than $\frac{3 \pi}{2}\left(\frac{N}{6}\right)^{\frac{1}{3}}$, and for $\theta>\frac{2 \pi}{3}$ it is equal to 2 .

Evidence. On a $360^{\circ}$ circle it is not possible to place more than two MPR nodes, the angle between which would be greater than $120^{\circ}$,

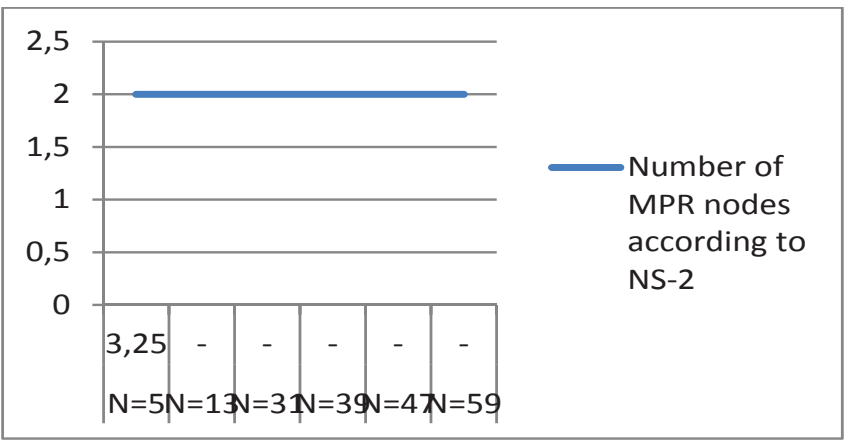

Fig. 5 Results of calculating the number of MPR nodes for the "tape" topology

otherwise the case is described by formula (3) for $\theta \leq \frac{2 \pi}{3}$

\section{Deviation from theoretical calculations}

Cases are found when calculations by formula (3) give a result that does not coincide with the results of simulation. This is true for networks with a topology in which each singlepoint node relative to the central node is an MPR node for the two-point node relative to the central one.

Four topologies of the network with the number of nodes $\mathrm{N}=9$ are considered; $17 ; 33$ and 65 (the first three of them are shown in Fig. 7), for which in Fig. 8 shows the number of MPR nodes received in accordance with (3) and simulation.

Fig. 8 shows that the theorem gives a correct result for the number of nodes $\mathrm{N}=9$, when 4 nodes are at the edge of the circle $2 \mathrm{R}$ relative to the central node. If the number of nodes at the edge of the circle $2 \mathrm{R}$ is increased by 2 times so that additional 4 nodes require additional $4 \mathrm{MPR}$ nodes to establish a connection, then the theoretical and practical results do not converge. Further increase of nodes (by 2 times) leads to even greater error. But it is also seen that the number of MPR nodes is exactly equal to the number of nodes that are on the verge of $2 \mathrm{R}$. 


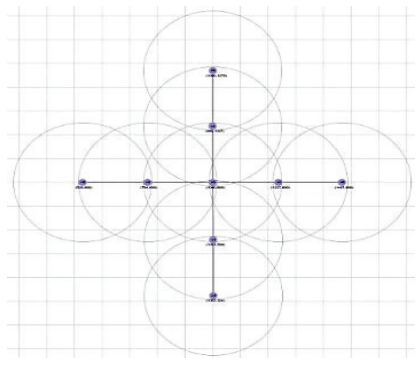

$80 \mathrm{M}$

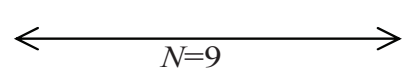

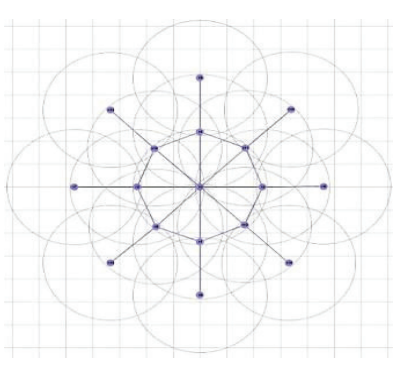

$80 \mathrm{M}$

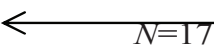

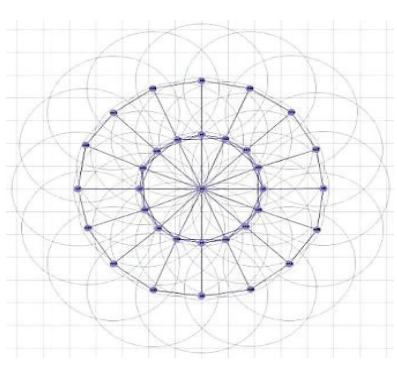

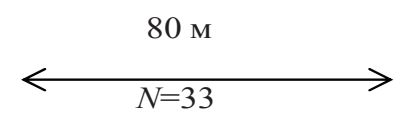

Fig. 7. Topologies in which each one-hinged neighbor relative to the central node is the MPR node for each two-point node

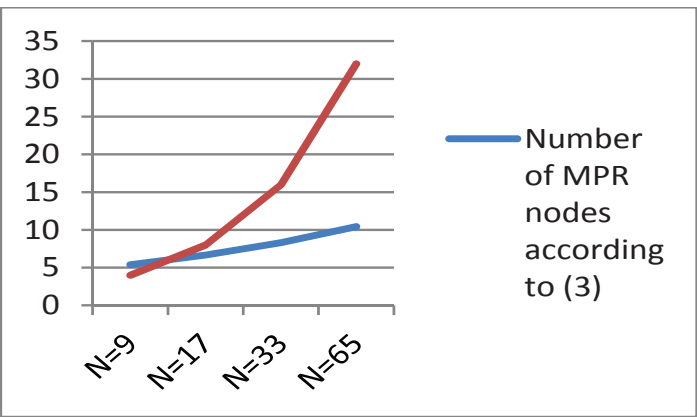

Fig.8 Results of calculating the number of MPR nodes

The deviation of the modeling results from theoretical calculations is due to the fact that the proof of the theorem was carried out under other conditions, namely: the process of selecting MPR nodes consists of selecting the nodes that are at the distance of reception of signals, that is closer to the boundary of the circle R; MPR nodes cover most of the neighbors at a distance of two slashes (that is, in a ring with radii $\mathrm{R}$ and $2 \mathrm{R}$, the density of the network is high and MPR nodes are actually on the border of $\mathrm{R}$.

By the results of the simulation, we can formulate the following addition to the theorem:

Theorem 1c. Regardless of the network density, each 2-hop node located at the boundary of the circle $2 \mathrm{R}$ requires its MPR node, which must be at the intersection of a circle with radius $\mathrm{R}$ and a radius $2 \mathrm{R}$ passing through the central node and the given 2-hop node.

Evidence. The 2-hop node located at the edge of the $2 \mathrm{R}$ circle may be in the receiving zone of the MPR of the node located at the edge of the circle R only in one case: when the MPR node is at the intersection of a circle with a radius $\mathrm{R}$ and a radius $2 \mathrm{R}$ that passes through the central node and this 2-hop node. Only in this case, the zone of action of the MPR node is tangent to a circle of
$2 \mathrm{R}$ at a single point, namely at the point where the 2-hop node is located

Hence it follows that for a given network topology, the number of MPR nodes is exactly equal to the number of dual-point nodes that are on the edge of the circle $2 \mathrm{R}$.

In Fig. 9, for various topologies, which are presented in Fig. 7, the uncovered reception area of MPR nodes (a painted part of the figures) is shown. We calculate the probability of finding two-point nodes at the boundary of the circle $2 \mathrm{R}$ for the represented topologies.

We find the probability of finding 2-hop nodes on the boundary of the circle $2 \mathrm{R}$ as the geometric probability of the data nodes reaching the uncovered reception area of single-point MPR nodes in the pursuit of a given area to zero, that is, before degeneration into a circle of radius $2 \mathrm{R}$.

For considered cases, we write this probability as $p=\frac{S_{\text {notcovered }}}{S_{\text {circle }}}, \quad$ where $S_{\text {notcovered }}=S(\theta)=R^{2}(\theta-\sin \theta), \quad \theta \leq \frac{2 \pi}{N_{M P R 1}} ;$ $N_{M P R 1}$ is the number of single-point MPR nodes, $\mathrm{S}_{\text {circle }}$ is the area of the ring bounded by the radii $\mathrm{R}$ i $2 \mathrm{R}$, which is equal to the $S_{\text {circle }}=\pi\left(4 R^{2}-\right.$ $\left.R^{2}\right)=3 \pi R^{2}$.

Taking into account the above, the probability of finding two-point nodes at the boundary of circle $2 \mathrm{R}$ will be written

$$
p=\frac{N_{M P R 1}}{3 \pi}\left(\frac{2 \pi}{N_{M P R 1}}-\sin \frac{2 \pi}{N_{M P R 1}}\right) \text {. }
$$

Imagine an uncovered area in the form of an equivalent ring with internal and external radii $\mathrm{Rh}$ and $2 \mathrm{R}$, respectively. Assuming that $\mathrm{R}=1$, the inner radius of the equivalent ring will be equal

$$
R_{x}=\sqrt{4-\frac{S_{\text {непокр }}}{\pi}}
$$




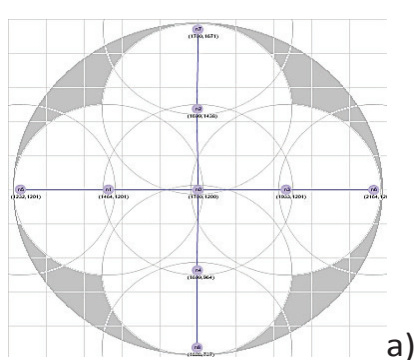

a)

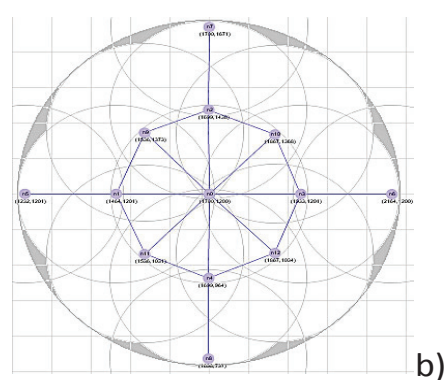

b)

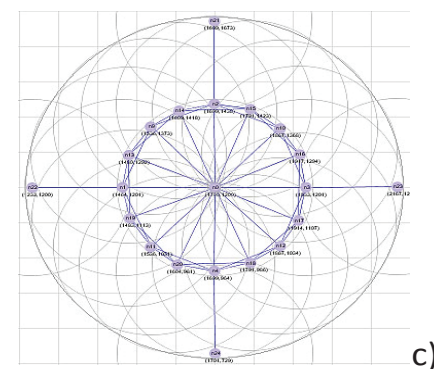

c)

Fig. 9. Uncovered area at different number of MPR nodes

In Table 1 calculations are given by formulae (6), (7), as well as absolute $\Delta \mathrm{R}$ and relative $\varepsilon$ deviation $\mathrm{Rh}$ from $2 \mathrm{R}$.

Table 1 .The probability of finding 2-hop nodes at the

\begin{tabular}{|c|c|c|c|c|}
\hline \multicolumn{6}{|c}{ boundary of circle $2 \mathrm{R}$} \\
\hline $\mathrm{N}_{\text {MPR1 }}$ & 4 & 8 & 16 & 32 \\
\hline$p$ & 0,2423 & 0,0665 & 0,0170 & 0,0043 \\
\hline$R_{x}$ & 1,9806 & 1,9947 & 1,9987 & 1,9997 \\
\hline$\Delta R=2 R-R_{x}$ & 0,0194 & 0,0053 & 0,0013 & 0,0003 \\
\hline$\varepsilon=\Delta R / 2 R, \%$ & 0,9686 & 0,2648 & 0,0676 & 0,0170 \\
\hline
\end{tabular}

Table 1 shows that the probability of locating 2-hop nodes at the circle boundary of radius $2 \mathrm{R}$ rapidly decreases: So for 17 nodes (8 MPR nodes), 7 cases are possible from 100, for 33 nodes (16 MPR) - 2 cases from 100, for 65 (32 MPR) - 5 cases from 1000. In this case, the internal radius of the equivalent ring for 17 knots differs from the outer at $0.0053(\varepsilon=0.26 \%)$, for 33 knots - by $0.0013(\varepsilon=0.07 \%)$, for 65 - to $0.0003(\varepsilon=0.02 \%)$.

It should be noted that the above was considered the worst case, when all two-walled nodes are located on the border of a circle with a radius of $2 \mathrm{R}$. If not to take into account the partial case, when each twin-collar neighbor needs its own MPR node, then formulae (3) and (4) give a reliable result.

\section{Conclusions}

1. In most cases considered, the real number of MPR nodes obtained by simulation in the NS-2 software package is always smaller than the upper number of MPR nodes, which is determined by the upper limit of the MPR nodes theorem.
2. The theorem on the upper limit can be written in simplified form:

When $\mathrm{R}$ is fixed and $\mathrm{N}$ is growing, then the upper limit of the number of MPR nodes $\mathrm{DN}$ at $\theta \leq 2 \pi / 3$ is less than $3 \pi / 2(N / 6)^{\wedge}(1 / 3)$, and for $\theta>2 \pi / 3$ it is equal to 2 .

3 . The deviation of the modeling results from theoretical calculations is explained by the fact that the conditions of the proof of the theorem did not take into account the cases of location of the nodes given in this paper. It is proved that, regardless of the network density, every two-point node located at the boundary of the $2 \mathrm{R}$ circle needs its MPR node, which must be at the intersection of a circle with radius $\mathrm{R}$ and a radius $2 \mathrm{R}$ passing through the central node and the given double-hinged node.

4. It is shown that the probability of the arrangement of 2-hop nodes on the boundary of a circle with radius $2 \mathrm{R}$ is small. So for 17 knots, 7 cases are possible from 100 , for 33 knots - 2 cases from 100 , for 65 - 5 cases from 1000 . In this case, the internal radius of the equivalent ring for 17 knots differs from the outer at 0.0053 (the relative deviation is $\varepsilon=0,26 \%$ ), for 33 knots - by 0.0013 ( $\varepsilon=0.07 \%)$, for 65 - by $0.0003(\varepsilon=0.02 \%)$.

It is planned to continue research in the direction of developing methods for reducing the official information, which is transmitted in the protocol OLSR. 


\section{References}

1. Vishnevsky V. Routing in broadband wireless 802.11 s MESH networks of the standard / V. Vishnevsky, D. Lakontsev, A. Safonov, S. Shpilev // ELECTRONICS: NAU, 2008, No. 6, p. 64-69.

2. Clausen T., Jacquet P. Optimized link state routing protocol (OLSR) // RFC 3626, IETF Network Working Group, - 2003.

3. Amir Qayyum, Laurent Viennot, Anis Laouiti Multipoint Relaying: An Efficient Technique for Flooding in Mobile Wireless Networks // // Institute national de recherche en informatique et en automatique, Theme 1 - Reseaux et systemes, Projet HIPERCOM, Rapport de recherché № 3898 -Mars 2000, 16 pages.

4. J.-M. Verbree, M. de Graaf, and J. Hurink, An analysis of the lifetime of olsr networks, Ad Hoc Netw., vol. 8, no. 4, pp. 391-399, 2010.

5. M. Voorhaen and C. Blondia, Analyzing the impact of neighbor sensing on the performance of the OLSR protocol, in Proceedings of 4th Intl. Symposium on Modeling and Optimization in Mobile, Ad Hoc, and Wireless Networks (WiOpt06), APRIL 2006.

6. Laurent Bouraoui, Arnaud De La Fortelle, and Anis Laouiti, OLSR improvement for distributed tracapplications, in Mediterranean Ad Hoc Networking Workshop, (Ile de Porquerolles, France), 062005.

7. A. Boukerche, L. Guardalben, J. B. M. Sobral, and M. S. M. A. Notare, A self-x approach for olsr routing protocol in large-scale wireless mesh networks, in GLOBECOM, pp. 778-783, 2008.

8. Philippe Jacquet, Anis Laouiti Pascale Minet Laurent Viennot. Performance analysis of OLSR Multipoint Relay flooding in two ad hoc wireless network models // Institut national de recherche en informatique et en automatique, Theme $1-$ Reseaux et systemes, Projet HIPERCOM, Rapport de recherché № 4260 - September, 2001. -26 pages. (https://hal.inria.fr/inria00072327/document).

9. Laouti Anis, Mühlethaler Paul, Najid Abdellah, Plakoo Epiphane. Simulation Results of the OLSR Routing Protocol for Wireless Network // Institute national de recherche en informatique et en automatique, Theme 1 - Reseaux et systemes, Projet HIPERCOM, Rapport de recherché № 4414 -March 2002, 24 pages.

10. Maksimov V.V. Calculation of the upper limit of the number of MPR nodes in the OLSR protocol / V.V. Maksimov, V.V. Polisnichenko, L.I. Potemkin // Collection of scientific proceedings of VITI NTUU "KPI". - 2012. - No. 1. - P.82-88.

\section{Максимов В.В. \\ Імітаційне дослідження верхньої межі кількості багатоточкових ретрансляторів протоколу} OLSR

Проблематика. В даний час затребуваність в мережах MANET визначають властиві цим мережам переваги перед стаціонарними мережами, особливо в умовах надзвичайних ситуацій. Топологія в таких мережах надзвичайно динамічна, що зажадало розробки спеціальних протоколів маршрутизації. Хоча основи теорії протоколу OLSR, який широко використовується в цих мережах, добре відомі, проте розвиток мереж рухомого зв'язку вимагає постійних уточнень теоретичних положень відповідно до нових даних про способи розрахунку кількості багатоточкових ретрансляторів.

Мета. Метою роботи є знаходження аналітичних виразів для розрахунку верхньої межі кількості багатоточкових ретрансляторів, ймовірності розташування двоскачкових вузлів на максимальній відстані від опорного і перевірки відповідності отриманих результатів за допомогою моделювання.

Методи. Використовуються аналітичні методи розрахунку, а також імітаційне моделювання в програмному пакеті NS-2.

Результати. Отримано аналітичні вирази для розрахунку верхньої межі кількості багатоточкових ретрансляторів і ймовірності розташування двоскачкових вузлів на максимальній відстані від опорного вузла. Проведено імітаційне моделювання з метою підтвердження теоретичних результатів. 
Висновки. Дана оцінка верхньої межі кількості односкачкових вузлів-ретрансляторів. Показано, що при малій щільності вузлів на даній площі величина верхньої межі в два рази менше раніше визначеної в науковій літературі. Моделювання в програмному пакеті NS-2 показало відповідність аналітичних виразів для розрахунку верхньої межі багатоточкових ретрансляторів. Наведено випадки відхилення від аналітичних розрахунків Для цих випадків доведено, що незалежно від щільності мережі кожен двоскачковий вузол, який знаходиться на максимальній відстані від опорного вузла, повинен мати свій багатоточечний ретранслятор. Визначено ймовірність розташування двоскачкових вузлів на максимальній відстані від опорного вузла.

Ключові слова: ad hoc мережа; OLSR протокол, многоточечний ретранслятор; кількість службової інформації; моделювання NS-2.

\section{Максимов В.В.}

Имитационное исследование верхней границы количества многоточечных ретрансляторов протокола OLSR

Проблематика. В настоящее время востребованность в сетях MANET определяют присущие этим сетям преимущества перед стационарными сетями, особенно в условиях чрезвычайных ситуаций. Топология в таких сетях чрезвычайно динамичная, что потребовало разработки специальных протоколов маршрутизации. Хотя основы теории протокола OLSR, который широко используется в этих сетях, хорошо известны, однако развитие сетей подвижной связи требует постоянных уточнений теоретических положений в соответствии с новыми данными о способах расчета количества многоточечных ретрансляторов.

Цель. Целью работы является нахождение аналитических выражений для расчета верхней границы количества многоточечных ретрансляторов, вероятности расположения двухскачковых узлов на максимальном расстоянии от опорного и проверки соответствия полученных результатов с помощью моделирования.

Методы. Используются аналитические методы расчета, а также имитационное моделирование в программном пакете NS-2.

Результаты. Получены аналитические выражения для расчета верхней границы количества многоточечных ретрансляторов и вероятности расположения двухскачковых узлов на максимальном расстоянии от опорного узла. Проведено имитационное моделирование с целью подтверждения теоретических результатов.

Выводы. Дана оценка верхней границы количества односкачковых узлов-ретрансляторов. Показано, что при малой плотности узлов на рассматриваемой площади величина верхней границы в два раза меньше ранее определенной в научной литературе. Моделирование в программном пакете NS-2 показало соответствие аналитических выражений для расчета верхней границы многоточечных ретрансляторов. Приведены случаи отклонения от аналитических расчетов. Для данных случаев доказано, что независимо от плотности сети каждый двухскачковый узел, который находится на максимальном расстоянии от опорного узла, должен иметь свой многоточечный ретранслятор. Определена вероятность расположения двухскачковых узлов на максимальном расстоянии от опорного узла.

Ключевые слова: ad hoc сеть; OLSR протокол; многоточечный ретранслятор; количество служебной информации; моделирование NS-2. 